\title{
Efficacy of eugenol and the methanolic extract of Condalia buxifolia during the transport of the silver catfish Rhamdia quelen
}

\author{
Alexssandro Geferson Becker ${ }^{1}$, Mauro Alves da Cunha $^{1}$, Luciano de Oliveira Garcia ${ }^{1}$, \\ Carla Cristina Zeppenfeld ${ }^{1}$, Thaylise Vey Parodi ${ }^{1}$, Graciela Maldaner ${ }^{2}$, \\ Ademir Farias Morel$^{2}$ and Bernardo Baldisserotto ${ }^{1}$
}

\begin{abstract}
This study evaluated extracts of Condalia buxifolia as anesthetics for the silver catfish Rhamdia quelen. The effectiveness of eugenol and of the methanolic extract (ME) of C. buxifolia during the transport of this species was also assessed. Fish of two different weights $(1.50 \pm 0.02 \mathrm{~g}$ and $165.70 \pm 22.50 \mathrm{~g})$ were transferred to aquaria containing water with the C. buxifolia ME or with fractions obtained from the ME, such as the $\mathrm{n}$-hexane, dichloromethane, ethyl acetate, $\mathrm{n}$-butane and aqueous fractions, at concentrations from $0-300 \mu \mathrm{L} \mathrm{L}^{-1}$. The $C$. buxifolia $\mathrm{ME}$ in the $0.5-120 \mu \mathrm{L} \mathrm{L}^{-1}$ range caused only light sedation, and the fractions did not have an effect on the fish. In the second experiment, another group of fish was transported for $12 \mathrm{~h}$ in 15 plastic bags. The fish were divided into five groups: control, 1 or $2.5 \mu \mathrm{L} \mathrm{L}^{-1}$ eugenol and 25 or $50 \mu \mathrm{L} \mathrm{L}^{-1}$ C. buxifolia ME. The non-ionized ammonia levels were lower at the end of transport in the groups with the compounds than in that with water alone. Moreover, both compounds decreased the $\mathrm{Na}^{+}, \mathrm{Cl}^{-}$, and $\mathrm{K}^{+}$net effluxes; therefore, their addition to the water during transport is advisable because they reduce fish mortality and ion loss.
\end{abstract}

Este estudo investigou extratos de Condalia buxifolia como anestésico para jundiá Rhamdia quelen, e também a eficiência do eugenol e do extrato metanólico (EM) de C. buxifolia para utilização durante o transporte dessa espécie. Peixes de dois diferentes pesos $(1,50 \pm 0,02 \mathrm{~g}$ e 165,70 $\pm 22,50 \mathrm{~g})$ foram transferidos para aquários contendo água com o EM de C. buxifolia ou frações obtidas a partir do EM (n-hexano, acetato de diclorometano, etil n- butano e aquoso, em concentrações na faixa de 0 - $300 \mu \mathrm{L} \mathrm{L}^{-1}$. O EM de C. buxifolia em concentrações na faixa de $0,5-120 \mu \mathrm{L} \mathrm{L}^{-1}$ causou somente uma sedação leve e as frações não tiveram efeito. No segundo experimento outro grupo de peixes foi transportado por $12 \mathrm{~h} \mathrm{em} 15$ sacos plásticos divididos em cinco tratamentos: controle, 1 ou $2,5 \mu \mathrm{L} \mathrm{L}^{-1}$ de eugenol e 25 ou $50 \mu \mathrm{L} \mathrm{L} \mathrm{L}^{-1}$ de EM de C. buxifolia. Os níveis de amônia nãoionizada foram menores nos tratamentos com ambos compostos em relação à água (controle). Além disso, ambos compostos diminuíram os efluxos líquidos de $\mathrm{Na}^{+}, \mathrm{Cl}^{-}$e $\mathrm{K}^{+}$e, portanto, sua adição na água de transporte é aconselhável, pois reduzem a mortalidade e a perda de íons dos peixes.

Key words: Anesthesia, Fish transport, Heptapteridae, Ion fluxes, Sedative.

\section{Introduction}

In the pursuit of new fish sedatives or anesthetics, researchers have searched for compounds that are easily acquired and of low cost to fish farmers. Moreover, these compounds should not present a risk to the health of the fish or the farmers, and the compounds should have little or no withdrawal period (Gilderhus \& Marking, 1987). It is also important that a new substance does not induce physiological and/or biochemical changes in the fish (Soto \& Burhanuddin, 1995; Anderson et al., 1997; Iversen et al., 2003; Façanha \& Gomes, 2005; Cunha et al., 2010a).
Plant extracts or essential oils appear to be viable alternatives as anesthetics for fish because of the high costs and difficulties of obtaining chemical products for this purpose (Façanha \& Gomes, 2005). Eugenol [(2-methoxy-4(2-propenyl) phenol], which is the major component in clove oil (70-90\% weight)], or clove oil has been used as an anesthetic in several studies with native Brazilian fish (Inoue et al., 2003, 2005; Roubach et al., 2005; Vidal et al., 2006, 2008; Barbosa et al., 2007; Gonçalves et al., 2008; Cunha et al., 2010b). Moreover, this anesthetic is listed in the FDA category of materials "generally regarded as safe" (Ross \& Ross, 2008). Because of their efficacy, low price, lack of

${ }^{1}$ Departamento de Fisiologia e Farmacologia, ${ }^{2}$ Departamento de Química, Universidade Federal de Santa Maria, 97105-900 Santa Maria, RS, Brazil. bbaldisserotto@hotmail.com (BB) 
withdrawal period and lack of negative effects on fish feeding, eugenol, clove oil and iso-eugenol have been considered "modish anesthetics" of choice in the aquaculture industry (Harper, 2003). However, eugenol impairs the flavor of the silver catfish, Rhamdia quelen, fillet; therefore, its use is not recommended immediately prior to slaughter (Cunha et al., 2010b).

The tree Condalia buxifolia Reissek (Rhamnaceae) is found primarily in South America, including in Brazil, Uruguay, and Argentina (Bastos, 1989), and a study of its chemistry identified several peptide alkaloids in its root bark (Morel et al., 2002). These peptide alkaloids possess a variety of biological activities, including sedation (ElSeedi et al., 2007).

The transport of live fish is problematic in aquaculture. The success of transporting fish depends on many factors, including the duration of transport, water parameters, the size, density and physical condition of the fish and the duration of the depuration period before fish transport (Berka, 1986; Golombieski et al., 2003; Carneiro et al., 2009; Becker et al., 2012). The most used system of juvenile transport in Brazil is the closed system that uses plastic bags. The limitations of this system are the supply of oxygen and the build-up of ammonia and carbon dioxide produced during transport (Gomes et al., 1999; Golombieski et al., 2003; Gomes et al., 2006a, b; Carneiro et al., 2009; Becker et al., 2012).

The use of anesthetics during fish transportation has been proposed to reduce stress responses (Guo et al., 1995; Inoue et al., 2005; Azambuja et al., 2011; Cunha et al., 2011; Becker et al., 2012). Monitoring physiological parameters, such as plasma ions, cortisol and glucose levels and ventilatory frequency, during transport can provide valuable data for the establishment of adequate management practices (Barton et al., 2003; Sulikowski et al., 2005; Carneiro et al., 2009; Becker et al., 2012).

Studies conducted on the transport of $R$. quelen have evaluated different times, densities, temperatures and salt concentration in the water (Gomes et al., 1999; Golombieski et al., 2003; Carneiro et al., 2009). Recently, a study on the effectiveness of eugenol (1.5 or $\left.3.0 \mathrm{iL} \mathrm{L}^{-1}\right)$ and of an essential oil of Lippia alba was performed that evaluated several blood and water parameters, survival and ionoregulatory balance (Becker et al., 2012).

The objective of this study was to evaluate the extracts of $C$. buxifolia as R. quelen anesthetics and to evaluate the time to induction and recovery from anesthesia. Moreover, this study investigated the effectiveness of eugenol and of the $C$. buxifolia methanolic extract (ME) for use during the transport of $R$. quelen using the following indicators: water parameters, mortality and ionoregulatory balance.

\section{Material and Methods}

\section{Plant material}

The freeze-dried bark of C. buxifolia $(2.2 \mathrm{~kg})$ was extracted with methanol $(\mathrm{MeOH})$ in a Soxhlet extractor. The solvent was evaporated under reduced pressure to obtain $430 \mathrm{~g}$ of a dark viscous residue (methanolic crude extract $\mathrm{ME})$. A portion of the ME (100 g) was dissolved in water $(500 \mathrm{~mL})$ and successively extracted with $\mathrm{n}$-hexane $(3 \times 0.5$ $\mathrm{L})$, dichloromethane $(3 \times 0.5 \mathrm{~L})$ and ethyl acetate $(3 \times 0.5 \mathrm{~L})$, yielding the following fractions: n-hexane $(10 \mathrm{~g})$, dichloromethane (7 g), ethyl acetate (5 g), n-butane (20.5 g) and aqueous $(55.5 \mathrm{~g})$. Identification of the botanical material was performed by comparison with existing samples in the herbarium of the Departamento de Biologia-UFSM (SMDB3296).

\section{Animals}

Specimens of $R$. quelen were purchased from a fish farm and transported to the Laboratory of Fish Physiology at the Universidade Federal de Santa Maria, where they were maintained for two weeks in continuously aerated $250 \mathrm{~L}$ tanks in a semi-static system (temperature $21 \pm 1^{\circ} \mathrm{C}, \mathrm{pH} 6.8 \pm 0.5$, dissolved oxygen $\left.6.5 \pm 0.8 \mathrm{mg} \mathrm{L}^{-1}\right)$. The fish were fasted for 24 $\mathrm{h}$ prior to the experiments. Two experiments were performed. Experiment I evaluated the anesthesia induction times in $R$. quelen exposed to extracts of C. buxifolia, and experiment II evaluated several physiological responses after the transport of $R$. quelen with eugenol and with the C. buxifolia ME added to the water during transport.

\section{Experiment I: Anesthesia induction in R. quelen exposed to extracts of $C$. buxifolia}

After the adaptation period to laboratory conditions, the fish ( $\mathrm{n}=260$ ) of two different weights (mean \pm SEM: $1.50 \pm 0.02$ $\mathrm{g}$ and $165.7 \pm 22.5 \mathrm{~g}$ ) were transferred to aquaria containing 1 $\mathrm{L}$ of water with one fish in each aquarium and with the $C$. buxifolia ME in the following concentrations: 0, 0.5, 1.0, 2.0, $3.0,4.0,5.0,10,30,50,80,120$, and $300 \mu \mathrm{L} \mathrm{L}^{-1}$ first diluted in ethanol at a proportion of 1:10. A previous analysis demonstrated that ethanol at the tested concentrations did not induce sedation or anesthesia in $R$. quelen (Cunha et al., 2010a). The time for anesthesia induction was evaluated according to Schoettger \& Julin (1967) (Table 1). The maximum observation time was $30 \mathrm{~min}$. The same procedure was used to test the other fractions of this extract, including the n-hexane, dichloromethane, ethyl acetate, n-butane and aqueous extracts. After these analyses, the fish were exposed to the C. buxifolia $\mathrm{ME}$ at $1.0-50 \mu \mathrm{L} \mathrm{L}^{-1}$ in continuously aerated $40 \mathrm{~L}$ tanks to determine whether $6 \mathrm{~h}$ of sedation would be anesthetic. This concentration range was chosen because sedation time increased at concentrations greater than $50 \mu \mathrm{L} \mathrm{L}^{-1}$ C. buxifolia $\mathrm{ME}$ (see results). After induction, the fish were transferred to anesthetic-free aquaria to eliminate any residue of the C. buxifolia extracts. The recovery time was not measured because sedation with the C. buxifolia ME was very light (see results) and the determination of full recovery would be imprecise. Twenty juveniles were used for each tested concentration, and each fish was used only once. The water parameters were the same as in the acclimation period. 
Table 1. Stages of anesthesia in fish (from Schoettger \& Julin, 1967).

\begin{tabular}{ccc}
\hline Stage & Description & Behavioral response \\
\hline 1 & Light sedation & Partial loss of reaction to external stimuli \\
2 & Deep sedation & Partial loss of equilibrium, no reaction to external stimuli \\
$3 \mathrm{a}$ & Total loss of equilibrium & Fish usually turn over but retain swimming ability \\
$3 \mathrm{~b}$ & Total loss of equilibrium & Swimming ability stops but responds to pressure on the caudal peduncle \\
4 & Anesthesia & Loss of reflex activity, no reaction to strong external stimuli \\
5 & Medullary collapse (death) & Respiratory movement ceases (death) \\
\hline
\end{tabular}

\section{Experiment II: Transport}

Another group of $R$. quelen $(\mathrm{n}=225$, mean \pm SEM: $12.01 \pm 1.73 \mathrm{~g}, 10.27 \pm 1.85 \mathrm{~cm}$ ) was captured using a cage net inside an earth pond at a fish farm near Santa Maria city, Southern Brazil. The fish did not go through a depuration period because this procedure, although recommended (Amend et al., 1982), is not followed by the majority of fish producers in southern Brazil (Golombieski et al., 2003). The fish were transported at a density of $186.7 \mathrm{~g} \mathrm{~L}^{-1}$ for $12 \mathrm{~h}$ in 15 plastic bags $(32 \times 60 \mathrm{~cm})$ with $1.5 \mathrm{~L}$ of water and $3 \mathrm{~L}$ of pure oxygen. The fish were divided into five treatment groups with three replicates each. These treatments were as follows: control, 1.0 or $2.5 \mu \mathrm{L} \mathrm{L}^{-1}$ eugenol (Odontofarma ${ }^{\mathrm{TM}}$, Porto Alegre, Brazil) (equivalent to 1.0 or $2.5 \mathrm{mg} \mathrm{L}^{-1}$, respectively, because the density of this anesthetic is approximately 1.06) and 25 or $50 \mu \mathrm{L} \mathrm{L}^{-1}$ C. buxifolia $\mathrm{ME}$ (both first diluted in ethanol 1:10). The transport time was defined as the maximum transport time utilized by the producers from Rio Grande do Sul State (Brazil), which is $12 \mathrm{~h}$. The selected eugenol concentrations were similar to those recommended by Becker et al. (2012) for the transport of the same species. The loading density used in this study was higher than the maximum recommended for silver catfish $\left(168 \mathrm{~g} \mathrm{~L}^{-1}\right)$ (Golombieski et $a l ., 2003)$ to expose the fish to a very stressful situation and to determine the efficacy of the substances used.

The water parameters were measured before and after transport. The dissolved oxygen (DO) and temperature were measured with an YSI oxygen meter (Model Y5512; YSI Inc., Yellow Springs, OH, USA). The $\mathrm{pH}$ was verified with a DMPH-2 pH meter (Digimed, São Paulo, SP, Brazil). Nesslerization verified the total ammonia nitrogen (TAN) levels according to the method of Eaton et al. (2005). Nonionized ammonia $\left(\mathrm{NH}_{3}\right)$ levels were calculated according to the method of Colt (2002). Water hardness was analyzed using the EDTA titrimetric method. Alkalinity was determined according to the method of Boyd \& Tucker (1992). Carbon dioxide $\left(\mathrm{CO}_{2}\right)$ was calculated using the method of Wurts \& Durborow (1992).

Water samples $(5 \mathrm{~mL})$ were collected before and after transport. Chloride levels were determined according to Zall et al. (1956), and $\mathrm{Na}^{+}$and $\mathrm{K}^{+}$levels were determined with a B262 flame spectrophotometer (Micronal, São Paulo, Brazil). Standard solutions were made with analytical-grade reagents dissolved in deionized water, and the standard curves of each ion to be tested were constructed for five different concentrations. The net ion fluxes (Jnet) were calculated according to the method of Gonzalez et al. (1998) as follows:

Jnet $=\mathrm{V}\left([\text { ion }]_{1}-[\text { ion }]_{2}\right) \times(\mathrm{Mxt})^{-1}$,

where [ion $]_{1}$ and [ion $]_{2}$ are the ion concentrations in the transport water at the beginning and end of the transport period, respectively, $\mathrm{V}$ is the water volume (L), $\mathrm{M}$ is the mass of the fish $(\mathrm{kg})$ and $\mathrm{t}$ is the duration of the transport $(\mathrm{h})$.

\section{Statistical analyses}

All data are expressed as the mean \pm SEM. The homogeneity of the variances between treatments was tested with Levene's test. The data exhibited homogeneous variances; therefore, comparisons among the different treatments and times were performed using a one-way ANOVA and Tukey's test. The analysis was performed using the Statistica ver. 7.0 software (Stat Soft. Inc., wwwstatsoft.com), and the minimum significance level was set at $\mathrm{P}<0.05$. The relation between the time to reach the stage of sedation and the concentration of the C. buxifolia ME was calculated with the Sigma Plot 11.0 software $(\mathrm{P}<0.05)$.

\section{Results}

\section{Experiment I: Anesthesia induction in $R$. quelen exposed to C. buxifolia extracts}

$R$. quelen exposed to the $\mathrm{n}$-hexane, dichloromethane, ethyl acetate, n-butane and aqueous extracts of C. buxifolia did not present any evidence of sedative or anesthetic effects during the $30 \mathrm{~min}$ evaluation period. The C. buxifolia $\mathrm{ME}$ at concentrations from $0.5-120 \mu \mathrm{L} \mathrm{L}^{-1}$ caused only light sedation (stage 1) in the $R$. quelen of both tested weights. Higher concentrations did not alter the silver catfish behavior within the $30 \mathrm{~min}$ evaluation period, and no difference was observed in the response to this extract between the two weight groups. In fish exposed to concentrations of the C. buxifolia ME greater than $10 \mu \mathrm{L} \mathrm{L}^{-}$ ${ }^{1}$, it was observed that the time to induce sedation increased as the concentration increased (Fig. 1). R. quelen exposed to $1.0-50.0 \mu \mathrm{L} \mathrm{L}^{-1} C$. buxifolia $\mathrm{ME}$ for $6 \mathrm{~h}$ maintained a uniform depth of sedation, i.e., they remained in stage 1 .

\section{Experiment II. Transport}

After transport, the highest mortality was observed in the control group followed by the $1 \mu \mathrm{L} \mathrm{L}^{-1}$ eugenol and 25 $\mu \mathrm{L} \mathrm{L}^{-1}$ C. buxifolia $\mathrm{ME}$ treatment groups. Conversely, the 


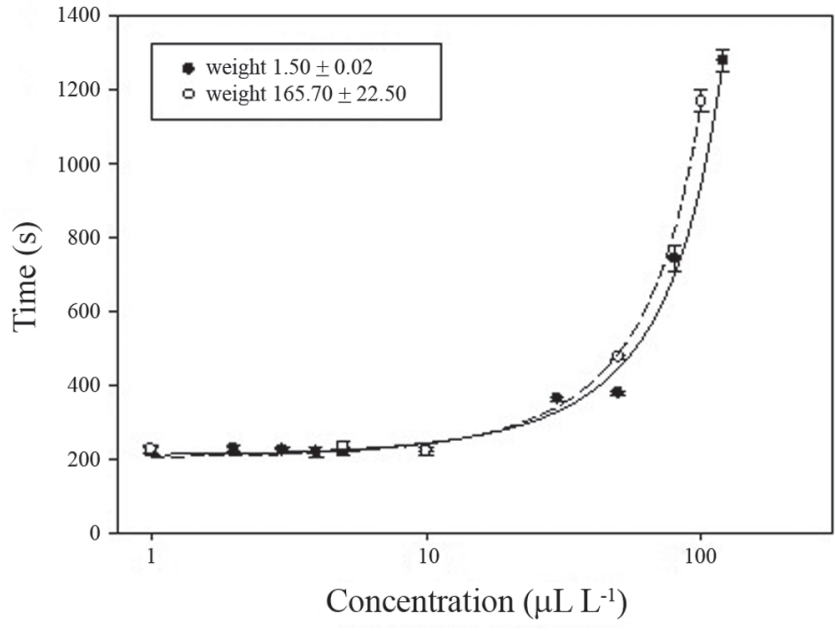

Fig. 1. Time to reach the light sedation stage in Rhamdia quelen juveniles of two different weight classes exposed to the methanolic extract of Condalia buxifolia. The following equations were fitted to the data: For fish weighing $1.50 \pm 0.02 \mathrm{~g}$; $\mathrm{y}=209.629 \mathrm{e}^{0.015 \mathrm{x}} ; \mathrm{r}^{2}=0.996$. For fish weighing $165.7 \pm 22.5 \mathrm{~g} ; \mathrm{y}=$ $2039.020 \mathrm{e}^{0.017 \mathrm{x}} ; \mathrm{r}^{2}=0.999$. Where $\mathrm{x}=$ the concentration of the methanolic extract of $C$. buxifolia $\left(\mu \mathrm{L} \mathrm{L}^{-1}\right)$ and $\mathrm{y}=$ time for sedation(s).

lowest mortality was observed in the $2.5 \mu \mathrm{L} \mathrm{L}^{-1}$ eugenol and $50 \mu \mathrm{L} \mathrm{L}^{-1}$ C. buxifolia ME treatment groups (Fig. 2).

The $1 \mu \mathrm{L} \mathrm{L}^{-1}$ eugenol and $25 \mu \mathrm{L} \mathrm{L}^{-1}$ C. buxifolia $\mathrm{ME}$ treatments exhibited the highest $\mathrm{DO}$ levels in the water after transport. Additionally, the lowest $\mathrm{CO}_{2}$ and TAN levels were found in the water of the control group. The total alkalinity, water hardness levels and water temperature did not exhibit any significant differences among the treatments at the end of transport. Additionally, the $\mathrm{pH}$ and $\mathrm{NH}_{3}$ levels were significantly higher in the control group than in the other groups (Table 2).

The net $\mathrm{Na}^{+}, \mathrm{Cl}^{-}$, and $\mathrm{K}^{+}$effluxes were significantly higher in the fish from the control treatment group than in the fish from the other treatment groups. Moreover, the lowest net $\mathrm{Na}^{+}, \mathrm{Cl}^{-}$, and $\mathrm{K}^{+}$effluxes were found for the $1 \mu \mathrm{L} \mathrm{L}^{-1}$ eugenol and $25 \mu \mathrm{L} \mathrm{L}^{-1}$ C. buxifolia ME treatment groups (Fig. 3).

\section{Discussion}

\section{Experiment I. Anesthesia induction in R. quelen exposed to C. buxifolia ME}

The $R$. quelen specimens were lightly sedated with the $C$. buxifolia ME, and there was no induction of anesthesia even after six hours. The recovery time of the C. buxifolia ME could not be precisely verified because the sedation was too light. Consequently, the use of this extract as a sedative rather than as an anesthetic is suggested. The best concentration range of the C. buxifolia $\mathrm{ME}$ appears to be $0.5-10 \mu \mathrm{L} \mathrm{L}^{-1}$ because higher concentrations increased the time of sedation

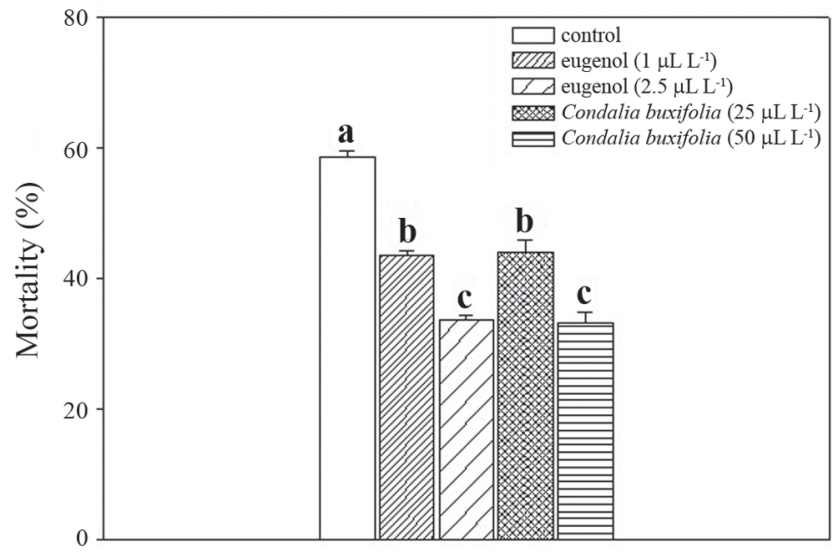

Fig. 2. Mortality after the transport of Rhamdia quelen in plastic bags with eugenol and with the methanolic extract of Condalia buxifolia added to the water. The values are the means \pm SEM. The different letters indicate significant differences between the treatments $(\mathrm{P}<0.05)$.

for both $R$. quelen weight classes. Additionally, this extract is very safe because even a concentration 30 -fold higher than the maximum concentration recommended did not cause mortality.

Because the fractions of the C. buxifolia ME did not present any sedative or anesthetic effects when tested separately, the effect of ME is most likely not due to a specific compound, which would have been separated in at least one of the fractions, but rather to the synergism of its compounds. There are no studies regarding the effects of these fractions of the C. buxifolia $\mathrm{ME}$ or even the synergism of compounds on anesthetizing fish, but the same principle can be found in some isolated components from the essential oil of two species of Ocimum that exhibited either low or no insecticidal activity and became potently toxic when blended together (Bekele \& Hassanali, 2001). Another interesting effect is that the time to reach the slight sedation stage increases in $R$. quelen exposed to higher concentrations of the C. buxifolia ME. Again, there are no similar results regarding fish anesthetics, but some interactions between plant compounds have revealed a clear concentration-dependent interaction (Goñi et al., 2009). It is possible that a concentration-dependent interaction occurs with the compounds of the $C$. buxifolia $\mathrm{ME}$ regarding its sedative effect in $R$. quelen. The lower efficacy of this ME at higher concentrations may be due to the increased concentration of minor compound(s) that antagonize the sedative effect. At lower concentrations, this compound would not effectively decrease the sedative effect.

\section{Experiment II: Transport}

In this study, there was significantly higher mortality in the control group than in the other treatment groups at the end of the transport period. Therefore, the anesthetics added 
Table 2. Water parameters before and after the transport (12 h) of Rhamdia quelen in plastic bags with eugenol and with the methanolic extract of Condalia buxifolia added to the water. The values are the means \pm SEM. The asterisks indicate significant differences compared to the values before transport $(\mathrm{P}<0.05)$. The different letters in the rows indicate significant differences between the treatments after transport $(\mathrm{P}<0.05)$. The dissolved oxygen and carbon dioxide levels are expressed as $\mathrm{mg} \mathrm{L}^{-1}$, and the total ammonia nitrogen and non-ionized ammonia are expressed as $\mathrm{mg} \mathrm{N} \mathrm{L}^{-1}$. The alkalinity and water hardness are expressed as $\mathrm{mg} \mathrm{CaCO}_{3} \mathrm{~L}^{-1}$.

\begin{tabular}{|c|c|c|c|c|c|c|}
\hline \multirow[b]{2}{*}{ Water parameter } & \multirow[b]{2}{*}{ Before transport } & \multicolumn{5}{|c|}{ After transport (treatments) } \\
\hline & & control & $\begin{array}{c}\text { eugenol } \\
(1 \mu \mathrm{L} L-1)\end{array}$ & $\begin{array}{c}\text { eugenol } \\
(2.5 \mu \mathrm{L} \text { L-1) }\end{array}$ & $\begin{array}{l}\text { C. buxifolia } \\
(25 \mu \mathrm{L} \mathrm{L}-1)\end{array}$ & $\begin{array}{l}\text { C. buxifolia } \\
(50 \mu \mathrm{L} \mathrm{L}-1)\end{array}$ \\
\hline$\overline{\text { Dissolved oxygen }}$ & $5.60 \pm 0.06$ & $1.46 \pm 0.06 * \mathrm{~d}$ & $2.22 \pm 0.09 * a$ & $1.73 \pm 0.04 * \mathrm{c}$ & $2.22 \pm 0.04 * a$ & $1.97 \pm 0.04 * b$ \\
\hline Carbon dioxide & $4.86 \pm 0.11$ & $51.04 \pm 1.33 * \mathrm{c}$ & $85.07 \pm 1.12 * \mathrm{a}$ & $78.48 \pm 1.27 * b$ & $79.04 \pm 1.77 * b$ & $76.60 \pm 2.13 * b$ \\
\hline Alkalinity & $24.7 \pm 0.5$ & $43.0 \pm 0.5 * \mathrm{a}$ & $45.2 \pm 1.3 * \mathrm{a}$ & $41.7 \pm 0.8 * \mathrm{a}$ & $42.0 \pm 0.5 * \mathrm{a}$ & $40.7 \pm 2.7 * \mathrm{a}$ \\
\hline Water hardness & $21.6 \pm 0.5$ & $26.5 \pm 0.5 * \mathrm{a}$ & $28.0 \pm 0.5 * \mathrm{a}$ & $28.0 \pm 0.5 * \mathrm{a}$ & $26.5 \pm 0.5 * \mathrm{a}$ & $26.5 \pm 0.5 * \mathrm{a}$ \\
\hline $\mathrm{pH}$ & $6.98 \pm 0.09$ & $6.21 \pm 0.05 * \mathrm{a}$ & $6.04 \pm 0.04 * b$ & $6.05 \pm 0.04 * b$ & $6.03 \pm 0.05 * b$ & $6.03 \pm 0.06 * b$ \\
\hline Temperature & $23.1 \pm 0.2$ & $28.1 \pm 0.3 * \mathrm{a}$ & $28.1 \pm 0.2 * \mathrm{a}$ & $28.1 \pm 0.2 * \mathrm{a}$ & $28.1 \pm 0.2 * \mathrm{a}$ & $28.1 \pm 0.3 * \mathrm{a}$ \\
\hline Total ammonia nitrogen & $0.10 \pm 0.02$ & $5.25 \pm 0.12 * \mathrm{c}$ & $6.12 \pm 0.12 * \mathrm{a}$ & $5.73 \pm 0.09 * b$ & $5.58 \pm 0.09 * b$ & $5.66 \pm 0.10 * b$ \\
\hline Non-ionized ammonia & 0.0005 & $0.0060 * \mathrm{a}$ & $0.0047 * \mathrm{~b}$ & $0.0045 * \mathrm{~b}$ & $0.0042 * b$ & $0.0043 * \mathrm{~b}$ \\
\hline
\end{tabular}

to the transport water reduced the mortality of $R$. quelen. The transport of largemouth black bass (Micropterus salmoides) with MS-222 (Carmichael et al., 1984) and of Indian major carp fry (Catla catla, Labeo rohita, and Cirrhinus mrigala) (Singh et al., 2004) and guppies (Poecilia reticulata) (Teo et al., 1989) with 2-phenoxyethanol also decreased mortality after transport.

The lethal concentrations ( $96 \mathrm{~h}$ ) of TAN and $\mathrm{NH}_{3}$ for $R$. quelen under normoxic conditions (total hardness: $20 \mathrm{mg}$ $\mathrm{CaCO}_{3} \mathrm{~L}^{-1} ; 25^{\circ} \mathrm{C}$ ) are 7.73 and $0.44 \mathrm{mg} \mathrm{L}^{-1}$, respectively, at $\mathrm{pH}$ 6.0 (Miron et al., 2008). In this study, the total ammonia and $\mathrm{NH}_{3}$ levels were much lower at the end of transport than the

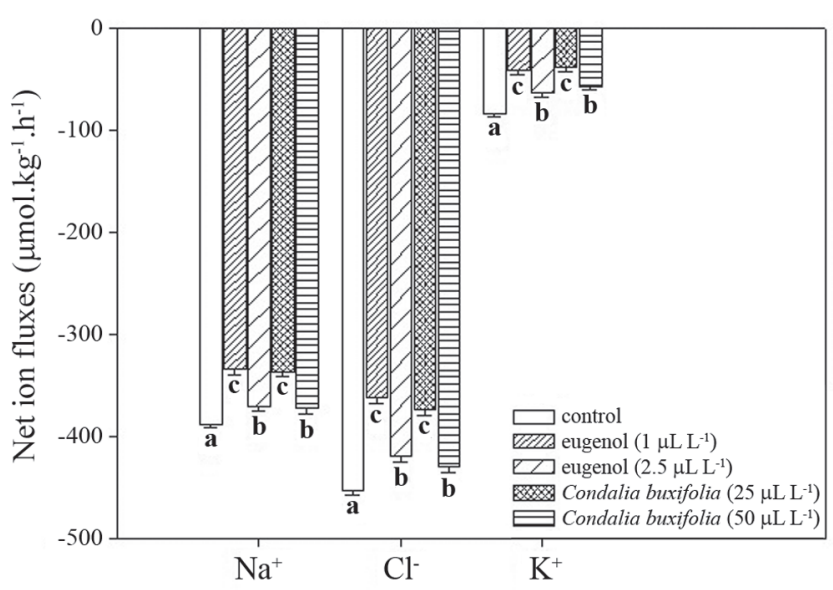

Fig. 3. The net ion $\left(\mathrm{Na}^{+}, \mathrm{Cl}^{-}\right.$and $\left.\mathrm{K}^{+}\right)$fluxes measured for the transport of Rhamdia quelen in plastic bags with eugenol and with the methanolic extract of Condalia buxifolia added to the water. The values are the means \pm SEM. The different letters indicate significant differences between the treatments for the same ion $(\mathrm{P}<0.05)$. lethal values, but the DO levels were very low and near the lethal concentration for $R$. quelen (Braun et al., 2006). Additionally, exposure to high waterborne $\mathrm{NH}_{3}\left(0.1 \mathrm{mg} \mathrm{L}^{-1}\right)$ and low DO (3.5 $\left.\mathrm{mg} \mathrm{L}^{-1}\right)$ levels for 6 and $24 \mathrm{~h}$ caused ionoregulatory changes in this species (Becker et al., 2009). Therefore, the low DO levels and high $\mathrm{NH}_{3}$ levels found in the control treatment group may explain the increase in mortality for this group.

Rhamdia quelen exposed to concentrations of eugenol between 20 and $70 \mu 1 \mathrm{~L}^{-1}$ could reach stage 2 anesthesia, i.e., deep sedation, which is observed as a partial loss of equilibrium and lack of reaction to external stimuli, within a few minutes (Cunha et al., 2010b). Conversely, R. quelen exposed to concentrations of the C. buxifolia ME between 1.0 and $50 \mu \mathrm{L}$ $\mathrm{L}^{-1}$ for $6 \mathrm{~h}$ maintained a uniform sedation in that they remained in stage 1. During the transport of the fish, the anesthetic concentrations must induce stage 2 anesthesia at most. Carmichael et al. (1984) reported increased survival and reduced stress parameters, such as decreased plasma glucose and corticosteroids and increased plasma $\mathrm{Cl}^{-}$and osmolality, during the transport of the largemouth black bass Micropterus salmoides in water with MS-222. Moreover, the use of benzocaine-hydrochloride $\left(25 \mathrm{mg} \mathrm{L}^{-1}\right)$ on the Mozambique tilapia Oreochromis mossambicus reduced oxygen consumption by approximately $1 / 3$ and decreased both ammonia and $\mathrm{CO}_{2}$ excretion (Ferreira et al., 1984). Additionally, the Indian carp fry C. catla, L. rohita, and C. mrigala exposed to 2-phenoxyethanol $\left(0.09 \mathrm{mg} \mathrm{L}^{-1}\right)$ exhibited decreased $\mathrm{NH}_{3}$ excretion (Singh et al., 2004). Park et al. (2009) suggested that lidocaine hydrochloride at concentrations of 5,10 or $20 \mathrm{mg} \mathrm{L}^{-1}$ decreased the metabolic activity of the flounder Pleuronectes americanus (= Pseudopleuronectes americanus) compared to that of the control group after $5 \mathrm{~h}$ of transport time because this substance reduced ammonia excretion (approximately 27.4 to $30.5 \%$ ) and oxygen consumption (approximately 82.7 to $86 \%$ ).

The increase in the $\mathrm{CO}_{2}$ levels observed in all treatment groups at the end of $R$. quelen transport was most likely 
responsible for the decrease in the $\mathrm{pH}$ of the water, which was similar to that observed by Golombieski et al. (2003) and Becker et al. (2012). Regardless of the treatment, the alkalinity levels increased after transport, most likely due to regurgitated food because the fish did not undergo a depuration period and the commercial food provided to the fish contained calcitic limestone $\left(\mathrm{CaCO}_{3}\right)$. Similar results were found by Golombieski et al. (2003) and Becker et al. (2012).

Transportation and handling operations are stressful situations that can increase ion loss in freshwater fish by increasing gill blood flow and paracellular permeability (Cech Jr. et al., 1991). In the present study, eugenol and the $C$. buxifolia ME in the transport water reduced ion loss in $R$. quelen. These results were similar to those of the same species transported with 1.5 or $3.0 \mu \mathrm{L} \mathrm{L}^{-1}$ eugenol and 10 or $20 \mu \mathrm{L} \mathrm{L}^{-1}$ L. alba essential oil added to the transport water for $4 \mathrm{~h}$ (Becker et al., 2012). Additionally, other studies have reported that the anesthetics used for fish transport reduced agitation and fish stress (Guo et al., 1995; Singh et al., 2004; Park et al., 2009). Therefore, eugenol and the C. buxifolia ME may have sedated the $R$. quelen during transport and reduced ion loss.

In conclusion, the best concentration range for the $C$. buxifolia $\mathrm{ME}$ is $0.5-10 \mu \mathrm{L} \mathrm{L}^{-1}$ because higher concentration levels increase the time of sedation. Moreover, the addition of eugenol and of the C. buxifolia $\mathrm{ME}$ to the transport water at the concentrations tested is advisable because they reduce fish mortality and ion loss.

\section{Acknowledgments}

This study was supported by Fundação de Amparo à Pesquisa do Estado do Rio Grande do Sul (FAPERGS/ PRONEX, process 10/0016-8) and Conselho Nacional de Pesquisa e Desenvolvimento Científico (CNPq, process 470964/2009-0). B. Baldisserotto and L.O. Garcia received a research fellowship, and A.G. Becker and C.C. Zeppenfeld received $\mathrm{PhD}$ fellowships from CNPq. T.V. Parodi and M.A. Cunha received Ph.D. fellowship from Coordenação de Aperfeiçoamento de Pessoal de Nível Superior (CAPES).

\section{Literature Cited}

Amend, N. F., T. R. Croy, B. A. Goven, K. A. Johnson \& D. H. McCarthy. 1982. Transportation of fish in closed systems: methods to control ammonia, carbon dioxide, $\mathrm{pH}$ and bacterial growth. Transactions of the American Fisheries Society, 111: 603-611.

Anderson, W. G., R. S. Mckinley \& M. Colavecchia. 1997. The use of clove oil as an anesthetic for rainbow trout and its effects on swimming performance. North American Journal of Fisheries Management, 17: 301-307.

Azambuja, C. R., J. Mattiazzi, A. P. K. Riffel, I. A. Finamor, L. O. Garcia, C. G. Heldwein, B. M. Heinzmann, B. Baldisserotto, M. A. Pavanato \& S. F. Llesuy. 2011. Effect of the essential oil of Lippia alba on oxidative stress parameters in silver catfish (Rhamdia quelen) subjected to transport. Aquaculture, 319: 156161.
Barbosa, L. G., G. Moraes \& L. A. K. A. Inoue. 2007. Respostas metabólicas do matrinxã submetido a banhos anestésicos de eugenol. Acta Scientiarum - Biological Sciences, 29: 255-260.

Barton, B. A., A. H. Haukenes, B. G. Parsons \& J. R. Reed. 2003. Plasma cortisol and chloride stress responses in juvenile walleyes during capture, transport, and stocking procedures. North American Journal of Aquaculture, 65: 210-219.

Bastos, N. R. 1989. A família Rhamnaceae R.Br. no Rio Grande do Sul: Gêneros Condalia (Cavanilles) e Scuttia Comm. ex Brogn. Pesquisas Botânicas, 40: 69-84.

Becker, A. G., L. O. Garcia, D. Kochhann, J. F. Gonçalves, V. L. Loro \& B. Baldisserotto. 2009. Dissolved oxygen and ammonia levels in water that affect plasma ionic content and gallbladder bile in silver catfish. Ciência Rural, 39: 1768-1773.

Becker, A. G., T. V. Parodi, C. G. Heldwein, C. C. Zeppenfeld, B. M. Heinzmann \& B. Baldisserotto. 2012. Transportation of silver catfish, Rhamdia quelen, in water with eugenol and the essential oil of Lippia alba. Fish Physiology and Biochemistry, 38: 789-796.

Bekele, J. \& A. Hassanali. 2001. Blend effects in the toxicity of the essential oil constituents of Ocimum kilimandscharicum and Ocimum kenyense (Labiateae) on two post-harvest insect pests. Phytochemistry, 57: 385-391.

Berka, R. 1986. The transport of live fish: a review. EIFAC Technical Papers 48, FAO, Rome.

Boyd, C. E. \& C. S. Tucker. 1992. Water quality and pond soil analyses for aquaculture. Alabama Agricultural Experiment Station, Auburn University, Alabama, USA.

Braun, N., R. L. Lima, B. Moraes, V. L. Loro \& B. Baldisserotto. 2006. Survival, growth and biochemical parameters of silver catfish, Rhamdia quelen (Quoy \& Gaimard, 1824), juveniles exposed to different oxygen levels. Aquaculture Research, 37: 1524-1531.

Carmichael, G. J., J. R. Tomasso, B. A. Simco \& K. B. Davis. 1984. Characterization and alleviation of stress associated with hauling largemouth bass. Transactions of the American Fisheries Society, 113: 778-785.

Carneiro, P. C. F., P. H. S. Kaiseler, E. A. C. Swarofsky \& B. Baldisserotto. 2009. Transport of jundiá Rhamdia quelen juveniles at different loading densities: water quality and blood parameters. Neotropical Ichthyology, 7: 283-288.

Cech Jr., J. J., S. D. Bartholow, P. S. Young \& T. E. Hopkins. 1996. Striped bass exercise and handling stress in freshwater: physiological responses to recovery environment. Transactions of the American Fisheries Society, 125: 308-320.

Colt, J. 2002. Fish Hatchery Management, appendices. American Fisheries Society. Available from: http://www.sheries.org/afs/ hatchery.html).

Cunha, M. A., F. M. C. Barros, L. O. Garcia, A. P. L. Veeck, B. M. Heinzmann, V. L. Loro, T. Emanuelli \& B. Baldisserotto. 2010a. Essential oil of Lippia alba: a new anesthetic for silver catsh, Rhamdia quelen. Aquaculture, 306: 403-406.

Cunha, M. A., L. O. Garcia, V. L. Loro, M. B. Fonseca, T. Emanuelli, A. P. L. Veeck, C. E. Copatti \& B. Baldisserotto. 2010 b. Anesthesia of silver catsh with eugenol: time of induction, cortisol response and sensory analysis of llet. Ciência Rural, 40: 2107-2114.

Cunha, M. A., B. F. Silva, F. A. C. Delunardo, S. C. Benovit, L. C. Gomes, B. M. Heinzmann \& B. Baldisserotto. 2011. Anesthetic induction and recovery of Hippocampus reidi exposed to the essential oil of Lippia alba. Neotropical Ichthyology, 9: 683688 . 
Eaton, A. D., L. S. Clesceri, E. W. Rice \& A. E. Greenberg. 2005. Standard methods for the examination of water and wastewater, $21^{\text {st }}$ ed. American Public Health Association, USA.

El-Seedi, H. R., M. H. Zahra, U. Goransson \& R. Verpoorte. 2007. Cyclopeptide alkaloids. Phytochemistry Reviews, 6: 143-165.

Façanha, M. F. \& L. C. Gomes. 2005. A eficácia do mentol como anestésico para tambaqui (Colossoma macropomum, Characiformes: Characidae). Acta Amazonica, 35: 71-75.

Ferreira, J. T., H. J. Schoonbee \& G. L. Smith. 1984. The use of benzocaine-hydrochloride as an aid in the transport of sh. Aquaculture, 42: 169-174.

Gilderhus, P. A. \& L. L. Marking. 1987. Comparative efficacy of 16 anesthetic chemicals on rainbow trout. North American Journal of Fisheries Management, 7: 288-292.

Golombieski, J. I., L. V. F. Silva, B. Baldisserotto \& J. H. S. da Silva. 2003. Transport of silver catfish (Rhamdia quelen) fingerlings at different times, load densities, and temperatures. Aquaculture, 216: 95-102.

Gomes, L. C., C. A. R. M. Araújo-Lima, A. R. Chippari-Gomes \& R. Roubach. 2006a. Transportation of juvenile tambaqui (Colossoma macropomum) in a closed system. Brazilian Journal of Biology, 66: 493-502.

Gomes, L. C., E. C. Chagas, R. P. Brinn, R. Roubach, C. E. Coppati \& B. Baldisserotto. 2006b. Use of salt during transportation of air breathing pirarucu juveniles (Arapaima gigas) in plastic bags. Aquaculture, 256: 521-528.

Gomes, L. C., J. I. Golombieski, A. R. Chippari-Gomes \& B. Baldisserotto. 1999. Effect of the salt in the water for transport on survival and on $\mathrm{Na}^{+}$and $\mathrm{K}^{+}$levels of silver catfish, Rhamdia quelen, fingerlings. Journal of Applied Aquaculture, 9: 1-9.

Goñi, P., P. López, C. Sánchez, R. Gómez-Lus, R. Becerril \& C. Nerín. 2009. Antimicrobial activity in the vapour phase of a combination of cinnamon and clove essential oils. Food Chemistry, 116: 982-989.

Gonçalves, A. F. N., E. C. C. Santos, J. B. K. Fernandes \& L. S. Takahashi. 2008. Mentol e eugenol como substitutos da benzocaína na indução anestésica de juvenis de pacu. Acta Scientiarum - Animal Sciences, 30: 339-344.

Gonzalez, R. J., C. M. Wood, R. W. Wilson, M. L. Patrick, H. L. Bergman, A. Narahara \& A. L. Val. 1998. Effects of water $\mathrm{pH}$ and $\mathrm{Ca}^{2+}$ concentration on ion balance in fish of the Rio Negro, Amazon. Physiological Zoology, 71: 15-22.

Guo, F. C., L. H. Teo \& T. W. Chen. 1995. Effects of anaesthetics on the water parameters in simulated transport experiment of playsh, Xiphophorus maculatus (Günther). Aquaculture Research, 26: 265-271.

Harper, C. 2003. Status of clove oil and eugenol for anesthesia of fish. Aquaculture Magazine, 29: 41-42.

Inoue, L. A. K. A., L. O. B. Afonso, G. K. Iwama \& G. Moraes. 2005. Effects of clove oil on the stress response of matrinxã (Brycon cephalus) subjected to transport. Acta Amazonica, 35: 289-295.

Inoue, L. A. K. A., C. dos Santos Neto \& G. Moraes. 2003. Clove oil as anaesthetic for juveniles of matrinxã Brycon cephalus (Günther, 1869). Ciência Rural, 33: 943-947.

Iversen, M., B. Finstad, R. S. Mckinley \& R. A. Eliassen. 2003. The efficacy of metomidate, clove oil, Aqui- $\mathrm{S}^{\mathrm{TM}}$ and Benzoak ${ }^{\circledR}$ as anaesthetics in Atlantic salmon (Salmo salar L.) smolts, and their potential stress-reducing capacity. Aquaculture, 221: 549566.

Miron, D. S., B. Moraes, A. G. Becker, M. Crestani, R. Spanevello, V. L. Loro \& B. Baldisserotto. 2008. Ammonia and pH effects on some metabolic parameters and gill histology of silver catfish, Rhamdia quelen (Heptapteridae). Aquaculture, 277: 192-196.

Morel, A. F., C. A. Araújo, U. F. Silva, S. C. S. M. Hoelzel, R. Záchia \& N. R. Bastos. 2002. Antibacterial cyclopeptide alkaloids from the bark of Condalia buxifolia. Phytochemistry, 61: 561-566.

Park, I. S., M. O. Park, J. W. Hur, D. S. Kim, Y. J. Chang, Y. J. Kim, J. Y. Park \& S. C. Johnson. 2009. Anesthetic effects of lidocainehydrochloride on water parameters in simulated transport experiment of juvenile winter ounder, Pleuronectes americanus. Aquaculture, 294: 76-79.

Ross, L. G. \& B. Ross. 2008. Anaesthetic and sedative techniques for aquatic animals, $3^{\text {rd }}$ edition, Blackwell Publishing Ltd., Oxford.

Roubach, R., L. C. Gomes, F. A. L. Fonseca \& A. L. Val. 2005. Eugenol as an efcacious anaesthetic for tambaqui, Colossoma macropomum (Cuvier). Aquaculture Research, 36: 1056-1061.

Schoettger, R. A. \& M. Julin. 1967. Efcacy of MS-222 as an anesthetic on four salmonids, vol 13. Investigations in Fish Control, USA Department of the Interior, 1-15.

Singh, R. K., V. R. Vartak, A. K. Balange \& M. M. Ghughuskar. 2004. Water quality management during transportation of fry of Indian major carps, Catlacatla (Hamilton), Labeorohita (Hamilton) and Cirrhinus mrigala (Hamilton). Aquaculture, 235: 297-302.

Soto, C. G. \& G. Burhanuddin. 1995. Clove oil as a fish anaesthetic for measuring length and weight of rabbit fish (Siganus lineatus). Aquaculture, 135: 149-152.

Sulikowski, J. A., E. A. Fairchild, N. Rennels, W. H. Howell \& P. C. W. Tsang. 2005. The effects of tagging and transport on stress in juvenile winter flounder, Pseudopleuronectes americanus: implications for successful stock enhancement. Journal of the World Aquaculture Society, 36: 148-156.

Teo, L. H., T. W. Chen \& B. H. Lee. 1989. Packaging of the guppy, Poecilia reticulata for air transport in a closed system. Aquaculture, 78: 321-332.

Vidal, L. V. O., R. C. B. Albinati, A. C. L. Albinati \& G. R. de Mecêdo. 2006. Utilização do eugenol como anestésico para o manejo de juvenis de pintado (Pseudoplatystoma corruscans). Acta Scientiarum - Biological Sciences, 28: 275-279.

Vidal, L. V. O., R. C. B. Albinati, A. C. L. Albinati, A. D. de Lira, T. R. de Almeida \& G. B. Santos. 2008. Eugenol como anestésico para tilápia-do-Nilo. Pesquisa Agropecuária Brasileira, 43: 10691074.

Wurts, W. A. \& R. M. Durborow. 1992. Interactions of pH, carbon dioxide, alkalinity and hardness in fish ponds. Southern Regional Aquaculture Center Publication, 464: 1-4.

Zall, D. M., M. D. Fisher \& Q. M. Garner. 1956. Photometric determination of chlorides in water. Analytical Chemistry, 28: 1665-1678.

Submitted December 1, 2012 Accepted May 25, 2013 by Adalberto Val Published September 30, 2013 